\section{Dissociation of Bovine Casein Micelles by Dialysis}

\author{
Tomotada ONO, Ho Tan DAN \\ and Satoshi ODAGIRI \\ Department of Agricultural Chemistry, \\ Iwate University, Morioka \\ Received October 25, 1977
}

Many investigations on casein micelles have offered some micelle models. These models are different from one another. ${ }^{1)}$ It was reported recently that removal of calcium ion by dialysis ${ }^{2)}$ or reaction with complexing agents ${ }^{3,4)}$ leads to micelle dissociation, and then subunits were observed to be about $10 \mathrm{~nm}$ in diameter by means of freeze-etch electron microscopy by Schmidt and Buchheim. ${ }^{2)}$ Creamer and Berry ${ }^{52}$ suggested that the subunit is in equilibrium with its component caseins and that its size distributions are changed under various conditions of $\mathrm{pH}$, temperature, and etc. Furthermore, Schultz and Bloomfield ${ }^{6)}$ reported the isolation of oligomer (about $10 \mathrm{~nm}$ ) from casein micelles (prepared at $5^{\circ} \mathrm{C}$ ) by using of Biogel A-15 column. Although these results indicated that casein micelle consisted of subunit and so on, it is not clear how to assemble subunit in casein micelle because casein micelles for sample are prepared at $5^{\circ} \mathrm{C}$ and are various sizes. Therefore, in order to estimate the construction of casein micelle, the dissociation process of micelle was studied by using casein micelles in uniform size prepared at room temperature.

Skimmilk of less than $0.01 \%$ of fat content was prepared from bulk milk of Holstein cows, and used for experiments under the condition of previous papers. ${ }^{*}$ Ultrafiltrate of skimmilk was prepared using a ultrafiltration cell (Toyokagaku model UH-76) with membranefilter UK200 (cut-off molecular weight 200,000 ) at room temperature. Casein micelle in uniform size was prepared from skimmilk. Insoluble substance in skimmilk was removed by centrifugation at $1000 \times g$ for $30 \mathrm{~min}$ and the supernatant was centrifuged at $15,000 \times g$ at $20^{\circ} \mathrm{C}$ for $30 \mathrm{~min}$. The pellet was dispersed into the ultrafiltrate of skimmilk by a Potter-Elvehjem homogenizer, and centrifuged at $15,000 \times g$ for $30 \mathrm{~min}$. Repeating this procedure twice, the micelle in uniform size (above $100 \mathrm{~nm}$ in diameter) was prepared. This pellet was dispersed to $3 \%$ of the protein concentration in $0.01 \mathrm{~m}$ imidazole buffer ( $\mathrm{pH} 6.8$, ionic strength 0.07 ) containing $0.02 \%$ of $\mathrm{NaN}_{3}$. Proteolysis was inhibited by addition of trypsin inhibitor (Miles Labo. Ltd.) to this solution. ${ }^{7)}$ Each $20 \mathrm{ml}$ of casein micelle solution was rigidly packed in visking tube, and dialyzed against $0.01 \mathrm{M}$ imidazole buffer at $20^{\circ} \mathrm{C}$. Buffer was renewed at 2, 4, $6,12,18,24,36$, and $48 \mathrm{hr}$ after starting of dialysis. After $72 \mathrm{hr}$ the volume of micelle solution was few increased. After dialysis, dialyzates were centrifuged at $100,000 \times g$ for $30 \mathrm{~min}$. Protein concentration of pellet was determined by the method of Gornall et al. ${ }^{\text {8) }}$ Calcium was measured in the presence of $500 \mathrm{ppm}$ strontium by the method of Ono and Odagir ${ }^{\theta>}$ with a Hitachi 207 atomic absorption spectrophotometer. Determination of inorganic phosphorus was carried out according to Nakamura's modified method ${ }^{10)}$ of Allen's method. Size distribution of micelle was measured by employing a Hitachi HU-125E electron microscope. Sample micelles for observation were prepared by the method of Carroll et al. ${ }^{11)}$ using $1 \%$ glutaraldehyde as the fixative. The measurement of micelle diameter was due to our previous paper. ${ }^{12}$ )

As casein micelle solution was dialyzed against $\mathrm{Ca}$ free imidazole buffer, calcium and inorganic phosphorus were decreased and protein of pellet centrifuged at $100,000 \times g$ for $30 \mathrm{~min}$ was reduced. Casein micelle was dissociated by moving of salts from colloidal to soluble phase. After dialysis for 24 , and $48 \mathrm{hr}, \beta$-casein and $\kappa$-casein in pellets were decreased and those in supernatants were increased as well as the results of Bloomfield et al., ${ }^{\text {3) }}$ Ono et al. ${ }^{\text {) }}$ by complexing agents, and Watanabe et al. ${ }^{13)}$ by urea.

The dissociation of casein micelle by dialysis was observed by an electron microscope. Before dialysis a great part of micelles distributed at the range of above $100 \mathrm{~nm}$ as shown in Fig. 1. After $5 \mathrm{hr}$ of dialysis, particles were appeared below $100 \mathrm{~nm}$. After $10 \mathrm{hr}$, the micelles of above $100 \mathrm{~nm}$ were decreased, and most of them became below $80 \mathrm{~nm}$. After $24 \mathrm{hr}$ these

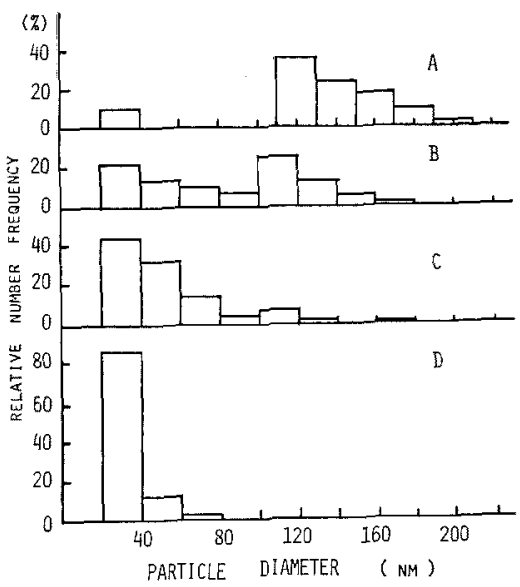

FIG. 1. Change of Size Distribution of Casein Particles in Uniform Size by Dialysis Time.

A: before dialysis, B: after $5 \mathrm{hr}, \mathrm{C}$ : after $10 \mathrm{hr}, \mathrm{D}$ : after $24 \mathrm{hr}$. 


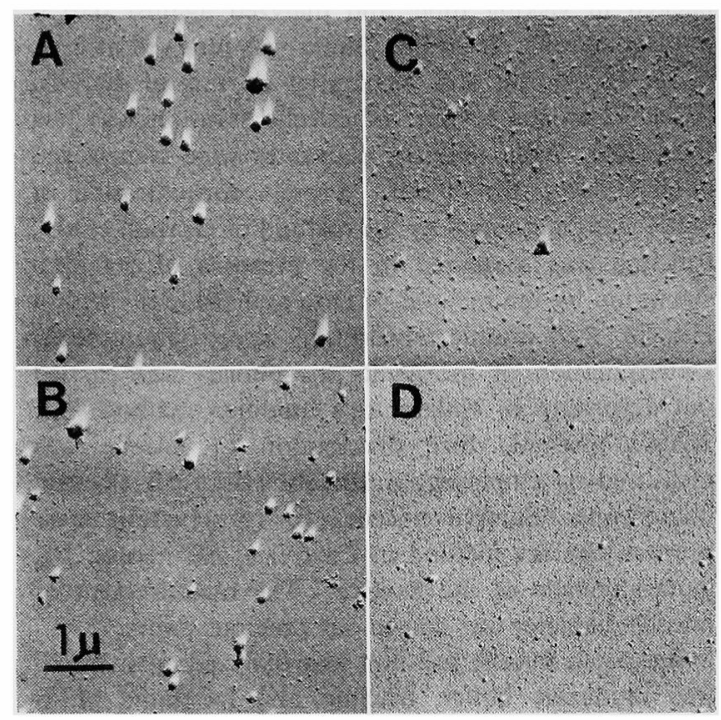

FIG. 2. Electron Micrographs of Sedimented Casein Particle $(100,000 \times g, 30 \mathrm{~min})$ in Dialysates of Uniform Micelle Solution.

Casein particle were fixed by $1 \%$ glutaraldehyde. A: before dialysis, B: after $5 \mathrm{hr}, \mathrm{C}$ : after $10 \mathrm{hr}, \mathrm{D}$ : after $24 \mathrm{hr}$.

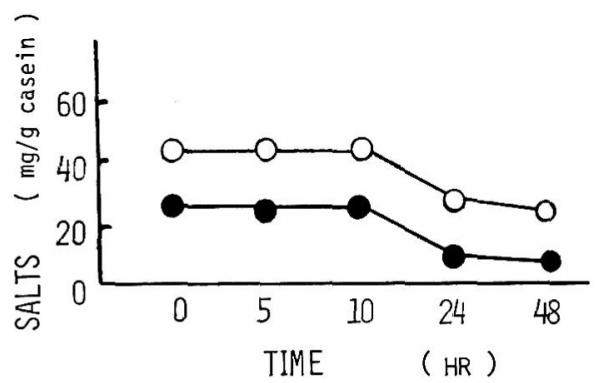

FIG. 3. Change of Salts Contents of Sedimented Pellets in Uniform Micelle Solution by Dialysis Time.

$\mathrm{O}$, calcium; $\bullet$, inorganic phosphorus.

particles almost dissociated to those of below $40 \mathrm{~nm}$. The electron micrographs of them are shown in Fig. 2. The native micelles were spherical shape as well as previous papers. ${ }^{411}$ ) The particles dissociated to below $100 \mathrm{~nm}$ showed spherical shape, too. Calcium and inorganic phosphorus contents in the native casein micelles were similar to those in smaller particles reformed up to $10 \mathrm{hr}$ of dialysis as shown in Fig. 3. These results may support that smaller particles were micelles derived from large micelles. The smallest particles observed after $24 \mathrm{hr}$ are considered to be subunit as well as those of Schmidt and Buchheim. ${ }^{2)}$ Therefore, large casein micelles may dissociate to subunit through smaller micelles by dialysis. The result is different from the framework model by Bloomfield et $a l^{3)}$ It is known that the micelle size relates closely to salts contents. ${ }^{4}$ Calcium and inorganic phosphorus contents of large and small micelles were almost same, but after $24 \mathrm{hr}$ of dialysis, their contents decreased as shown in Fig. 3. It means that the salts contents of subunit are lower than those to casein micelles. Therefore, casein micelles may be formed by connecting subunits mutually through calcium and inorganic colloidal calcium phosphate.

It is concluded that casein micelles are composed from calcium, colloidal calcium phosphate, $\beta$-casein, $\kappa$-casein, and subunit which consists of $\alpha_{\mathrm{s} 1^{-}}, \beta$-, and $\kappa$ casein, and that large casein micelles were reformed to small casein micelles and finally dissociated to subunit by release of salts, $\beta$-casein and $\kappa$-casein.

Acknowledgement. We would like to thank I. Tanimura who operated the electron microscope with great skill.

\section{REFERENCES}

1) H. M. Farrell, Jr., J. Dairy Sci., 56, 1195 (1973).

2) D. G. Schmidt and W. Buchheim, Milchwissenschaft, 25, 596 (1970).

3) S. H. C. Lin, R. K. Dewan, V. A. Bloomfield and C. V. Morr, Biochemistry, 11, 1818 (1972).

4) T. Ono, Y. Hayakawa and S. Odagiri, Nippon Nôgeikagaku Kaishi, 49, 417 (1975).

5) L. K. Creamer and G. P. Berry, J. Dairy Res., 42, 169 (1975)

6) B. C. Schultz and V. A. Bloomfield, Arch. Biochem. Biophys., 173, 18 (1976).

7) S. Kaminogawa, H. Mizobuchi and K. Yamauchi, Agric. Biol. Chem., 36, 2163 (1972).

8) A. G. Gornall, C. S. Bardwill and M. M. David, J. Biol. Chem., 177, 751 (1949).

9) T. Ono and S. Odagiri, Jap. J. Dairy Sci., 24, A-133 (1975).

10) M. Nakamura, Nippon Nôgeikagaku Kaishi, 24, 1 (1950).

11) R. J. Carroll, M. P. Thompson and G. C. Nutting, J. Dairy Sci., 51, 1903 (1969).

12) T. Ono, E. Kikuchi and S. Odagiri, Nippon Nôgeikagaku Kaishi, 51, 101 (1977).

13) M. Watanabe, I. Katou, K. Shimazaki, R. Niki and S. Arima, Jap. J. Zootech. Sci., 44, 148 (1973). 